\title{
Anthropization on the Cerrado biome in the Brazilian Uruçuí-Una Ecological Station estimated from orbital images
}

\author{
Pereira, AC.* and Gama, VF.* \\ ${ }^{a}$ Divisão de Sensoriamento Remoto - DSR, Instituto Nacional de Pesquisas Espaciais - INPE, \\ Av. dos Astronautas, 1758, CEP 12227-010, São José dos Campos, SP, Brazil \\ *e-mails: alfredo@dsr.inpe.br, veronica@dsr.inpe.br \\ Received August 17, 2009 - Accepted November 18, 2009 - Distributed November 30, 2010
}

(With 3 figures)

\begin{abstract}
In this study we analysed the dynamics of deforestation and burnings during the dry seasons from 2003 to 2008 in the Uruçuí-Una Ecological Station (UUES) and its buffer zone, located in the Cerrado biome of the southwest of Piauí, a Brazil's State, based on images from the orbital sensors CCD/CBERS-2 and TM/Landsat-5. Two dates from each of the years were interpreted and analysed: one in the middle of the dry season and one at the end. The deforested areas were expanded through the period analysed and were larger in the buffer zone, suggesting a relative protection of the UUES. New cut-offs were predictable because of the early opening of roads that would become their limits. The burning scars were larger at the end of the dry season as a consequence of the management and implementation of agricultures and pastures. In 2004 and 2007 these scars were larger probably because of the increase of dry phytomass that every three years is big enough to spread the fire originated in the anthropogenic burnings through the native vegetation. This scenario reaffirms the need for: stronger enforcement in order to stop anthropisation in the UUES and a management plan, absent for this unit so far. These proceedings are urgent also because the UUES is located in one of the most preserved regions of the Cerrado and controversially where intense anthropisation in ongoing, which stresses the lack, need and urgency of biological conservation proceedings for the Piauís southeastern Cerrado.
\end{abstract}

Keywords: savanna, fire, deforestation, CCD/CBERS, TM/Landsat.

\section{Antropização do bioma Cerrado na Estação Ecológica Uruçuí-Una estimada a partir de imagens orbitais}

\begin{abstract}
Resumo
Neste estudo, analisamos a dinâmica dos desmatamentos e queimadas do bioma Cerrado na Estação Ecológica UruçuíUna e sua zona tampão, localizada no sudoeste do Piauí, durante as estações secas de 2003 a 2008, com base em imagens dos sensores orbitais CCD/CBERS-2 e TM/Landsat-5. Duas datas de cada ano foram interpretadas e analisadas: uma em meados da estação seca e outra no final. A área desmatada expandiu-se no período analisado e foi maior na zona tampão, sugerindo uma proteção relativa da Estação Ecológica. Novos desmatamentos foram previsíveis devido a prévias aberturas de estradas e aceiros que posteriormente tornaram-se os limites das áreas exploradas. As queimadas foram maiores no período final do que no meio da estação seca em função da implantação e manejo das áreas agropecuárias. Em 2004 e 2007, as queimadas foram maiores provavelmente devido ao acúmulo de fitomassa seca que, a cada três anos, espalha facilmente pela vegetação nativa o fogo originado nas atividades antrópicas. Este cenário enfatiza a necessidade de reforçar a fiscalização para interromper a antropização na Estação Ecológica e de um plano de manejo, ainda ausente nesta Estação. Estas medidas são ainda mais urgentes pelo fato da Estação estar localizada em uma das regiões mais conservadas do Cerrado, mas, paradoxalmente, é onde está ocorrendo intensa antropização, o que realça a ausência, necessidade e urgência de medidas de conservação biológica para o Cerrado do sudoeste do Piauí.
\end{abstract}

Palavras-chave: savana, queimada, desmatamento, CCD/CBERS, TM/Landsat. 


\section{Introduction}

Cerrado is a type of savanna that occurs in Brazil, Paraguay and Bolivia. It is one of the largest Brazilian biomes and extends from the northeastern coast, through the centre of the country, until the western region (IBGE, 2004). Its original domain represents $21 \%$ of the national territory, approximately 2 million $\mathrm{km}^{2}$, however at least $48 \%$ percent of it has already been modified because of anthropisation (Mantovani and Pereira, 1998; Machado et al., 2004; MMA, 2009a). Studies of this biome are important for the maintenance of biodiversity and because it is the habitat of many endemic and migratory species that are at risk of extinction (Zaher, 2001; Aguiar et al., 2004).

Fire is one of the most important ecological features of the Cerrado, which can be started naturally or by the interference of man (França and Setzer, 2001; França et al., 2007). In the rainy season, from October to March, lightning occasionally start fires during rainstorms and, in this case, areas usually do not burn more than $1 \mathrm{~km}^{2}$ (França et al., 2007). However, man has been the principal cause of fire in the Cerrado from the earliest times (Coutinho, 1990), specially during the dry season, from April to September, when farmers burn areas for agriculture and cattle raising and the fire is spread through hundreds of kilometres of the Cerrado, in this case, with no rain to stop it (Coutinho, 1990; França et al., 2007).

In this study we quantify the deforestation and burning dynamics during the dry season from 2003 to 2008 in the Uruçuí-Una Ecological Station and its buffer zone using orbital images of the sensors CCD/CBERS-2 and TM/Landsat-5. This conservation area should provide protection to its ranges of Cerrado, spring waters, rivers and fauna. But the truth is its delicate natural equilibrium is endangered because of anthropisation. Burnings and the deforestation of large areas outside of the station, by farmers, and inside by "posseiros" (squatters) to promote agriculture and cattle raising are the biggest dangers to the ecosystems there (Zaher, 2001; IBAMA, 2004).

\section{Material and Method}

The study area is the Uruçuí-Una Ecological Station (UUES) and its buffer zone (BZ), which are located in one of the most preserved regions of the Cerrado biome (Mantovani and Pereira, 1998; Machado et al., 2004; MMA, 2009a,b), and nevertheless with higher rates of anthropisation (MMA, 2009a,b). This conservation area is located in Baixa Grande do Ribeiro city, in the southwest of Piauí State, Brazil (BRASIL, 1981; IBAMA, 2004), the third city in the Cerrado which had been deforested the most from 2002 to 2008 (MMA, 2009a). Buffer zone is the area evolving every Conservation Unit - among these Ecological Stations. It covers the $10 \mathrm{~km}$ extension from the borders of these Units and its use is restricted (BRASIL, 1990). The UUES limits are between latitudes $8^{\circ} 38^{\prime} \mathrm{S}$ and $9^{\circ} 05^{\prime} \mathrm{S}$ and longitudes $44^{\circ} 56^{\prime} \mathrm{W}$ and $45^{\circ} 33^{\prime} \mathrm{W}$ (see Figure 1). The UUES area is $203,426.91$ ha, its buffer zone, 239,375.34 ha, and the sum of both areas is $442,802.25$ ha.

\subsection{Material}

In this study we used: the Geographic Information System (GIS) software SPRING 4.3.3 (INPE, 2008a);
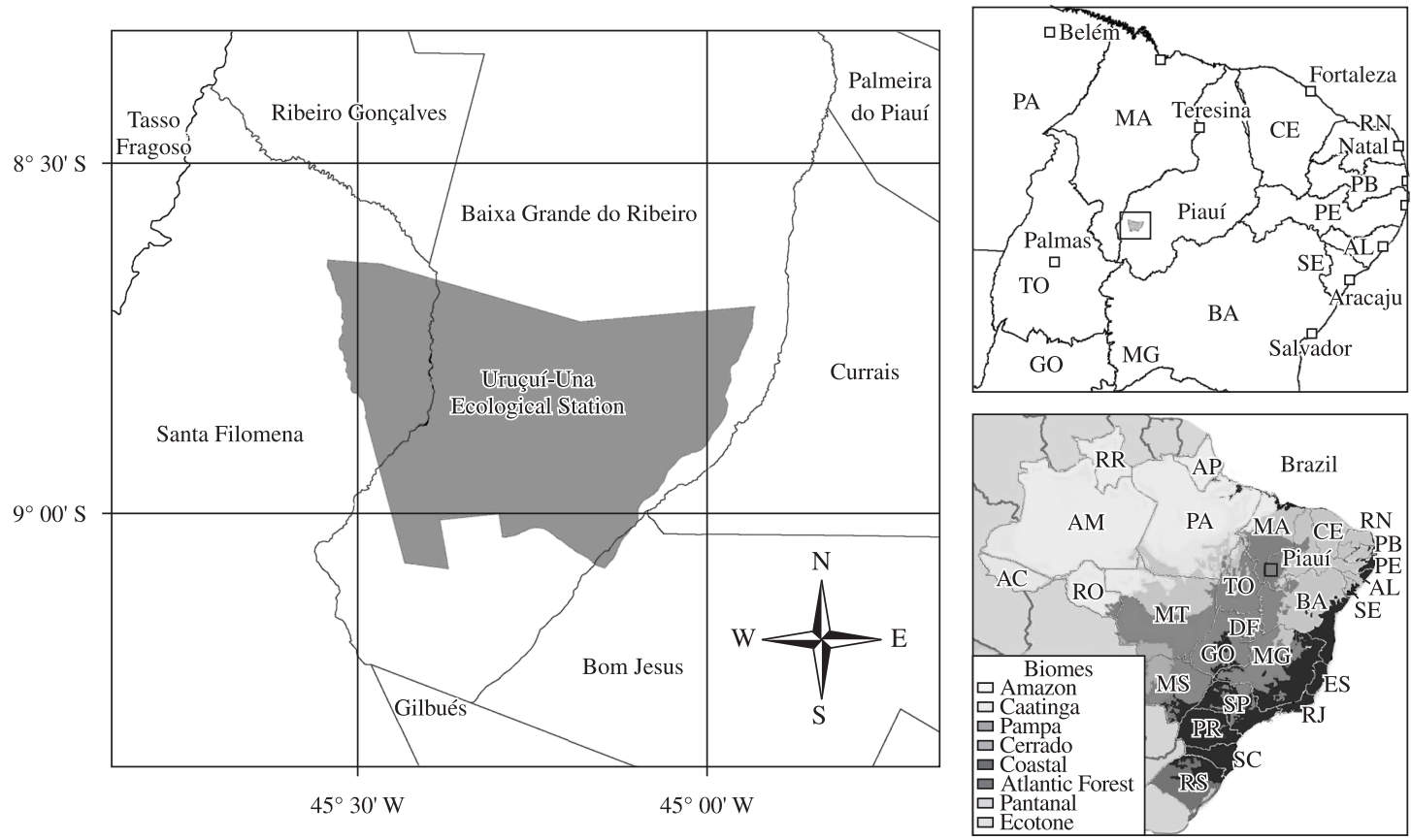

Figure 1. Location of the Uruçuí-Una Ecological Station in: a) Piauí's Southwest on the left; Brazil's Northeast on the upper right; and Brazil on the lower right (adapted from IBAMA, 2004). 
UUES limits (IBAMA, 2004); nine TM/Landsat-5 orbital sensor scenes path/row 220/66 (INPE, 2008b); four CCD/ CBERS-2 orbital sensor scenes path/row 156/110 and two 157/110 (INPE, 2008b); and one Landsat Geocover scene path/row 220/66 of August 30, 2001 (University of Maryland, 2009).

TM/Landsat-5 scenes cover a $185 \times 185 \mathrm{~km}$ area with spatial resolution of $30 \mathrm{~m}$ and CCD/CBERS-2 scenes cover a $113 \times 113 \mathrm{~km}$ area with $20 \mathrm{~m}$ of spatial resolution. The sensors spectral characteristics are shown in Table 1 (INPE, 2008b).

The images used are shown in Table 2, two for each of the years studied: one in the middle of the dry season (MS) and one in the end (ES). July images were available for all years in the middle of the dry season. However, the same wasn't true for the end so we chose the ones dating closer to October, which varied from August to November, depending on the year. Furthermore, because clouds covered parts of the study area in the image of September/2006, an August image was used as auxiliary.

\subsection{Method}

The images were georeferenced to the Geocover image. In addition to the images, the UUES limits were imported to SPRING 4.3.3 software and a layer with the limits of the buffer zone was created (see Figure 2).

Four thematic layers for each image were created using visual interpretation and raster edition: deforestation in the UUES; deforestation in the buffer zone; burning scars in the UUES; and burning scars in the buffer zone. For deforestation we made a sequential interpretation starting from the first image of 2003, with the generation of a layer that was copied to the layer of the next date and edited according to the interpretation of this new date. The burning scar layers were created by a sequential interpretation as well, but they were independent from the previous dates. The minimal area mapped was 4 ha in function of work scale 1:50.000

The interpretation was made over true and false colour composites. On TM images the true colour composite used was: band 3 on the blue channel, 4 on green and 5 on red (3B4G5R), and on CCD images: band 2 on blue, 3 on red and 4 on green (2B3R4G). On the false colour composite the colours green and red were inverted.

Table 1. Spectral characteristics of TM/Landsat-5 and CCD/ CBERS-2 orbital sensors.

\begin{tabular}{cccc}
\hline Band & \multicolumn{2}{c}{ Spectral interval $(\boldsymbol{\mu m})$} & \multirow{2}{*}{$\begin{array}{c}\text { Spectrum } \\
\text { portion }\end{array}$} \\
\cline { 2 - 3 } & TM & $\mathbf{C C D}$ & Blue \\
2 & $0.45-0.52$ & $0.45-0.52$ & Green \\
3 & $0.52-0.60$ & $0.52-0.59$ & Red \\
4 & $0.63-0.69$ & $0.63-0.69$ & Near infrared \\
5 & $0.76-0.90$ & $0.76-0.89$ & Mid infrared \\
6 & $1.55-1.75$ & & Thermal infrared \\
7 & $10.4-12.5$ & & Far infrared \\
\hline
\end{tabular}

Fundamental elements of the images like colour, texture, shape, size, shade and location were visually interpreted for the detection of the deforested and burned areas. The main characteristics of the deforestations were the polygonal shape, colours and texture (as shown in Table 3 ). The burning scars were detected mainly for their irregular shape and characteristic colours and texture (as shown in Table 3). Some regions, not used after their deforestation and/or burnings, were considered deforested or burned until the regrowth of the vegetation became similar to the surrounding native vegetation.

\section{Results}

In Brazil, the biggest expansion of agriculture and pasture frontiers has taken place in the Cerrado (Coutinho, 1990; Smith et al., 1998). In this study this expansion was predictable most of the time because of the opening of roads or "aceiros" forming squares that could be observed on the images. Then the native Cerrado vegetation inside these polygons was submitted to the process of slash or slash-burn and at last, new agricultures or pastures would be established. The total deforested areas increased $61 \%$ in the UUES, $73 \%$ in the buffer zone and $69 \%$ in both areas analysed as one, from July 2003 to September 2008.

In the UUES, buffer zone and both analysed together, the deforested areas were expanded through all periods and were a lot larger in the buffer: at least twice until three times as much (as shown in Table 4 and see Figure $3 a$ ). This fact indicates the relative protection of the UUES probably because farmers might give preference to deforest outside the preservation area in order to avoid legal problems.

According to some authors like Coutinho (1990), Pereira (1992) and França and Setzer (2001), the Cerrado fire season usually starts in May and peaks by late August and early September. This happens because farmers set

Table 2. Dates, sensors and path/row from orbital images.

\begin{tabular}{ccc}
\hline Date & Sensor & Path/ROW \\
\hline $27 / 07 / 2003$ & TM/Landsat-5 & $220 / 66$ \\
$16 / 11 / 2003$ & TM/Landsat-5 & $220 / 66$ \\
$13 / 07 / 2004$ & TM/Landsat-5 & $220 / 66$ \\
$17 / 10 / 2004$ & TM/Landsat-5 & $220 / 66$ \\
20/07/2005 & CCD/CBERS-2 & $156 / 110$ \\
$17 / 07 / 2005$ & CCD/CBERS-2 & $157 / 110$ \\
$07 / 09 / 2005$ & CCD/CBERS-2 & $157 / 110$ \\
$06 / 10 / 2005$ & CCD/CBERS-2 & $156 / 110$ \\
$19 / 07 / 2006$ & TM/Landsat-5 & $220 / 66$ \\
$14 / 08 / 2006$ & CCD/CBERS-2 & $156 / 110$ \\
$09 / 09 / 2006$ & CCD/CBERS-2 & $156 / 110$ \\
22/07/2007 & TM/Landsat-5 & $220 / 66$ \\
$24 / 09 / 2007$ & TM/Landsat-5 & $220 / 66$ \\
$08 / 07 / 2008$ & TM/Landsat-5 & $220 / 66$ \\
26/09/2008 & TM/Landsat-5 & $220 / 66$ \\
\hline
\end{tabular}




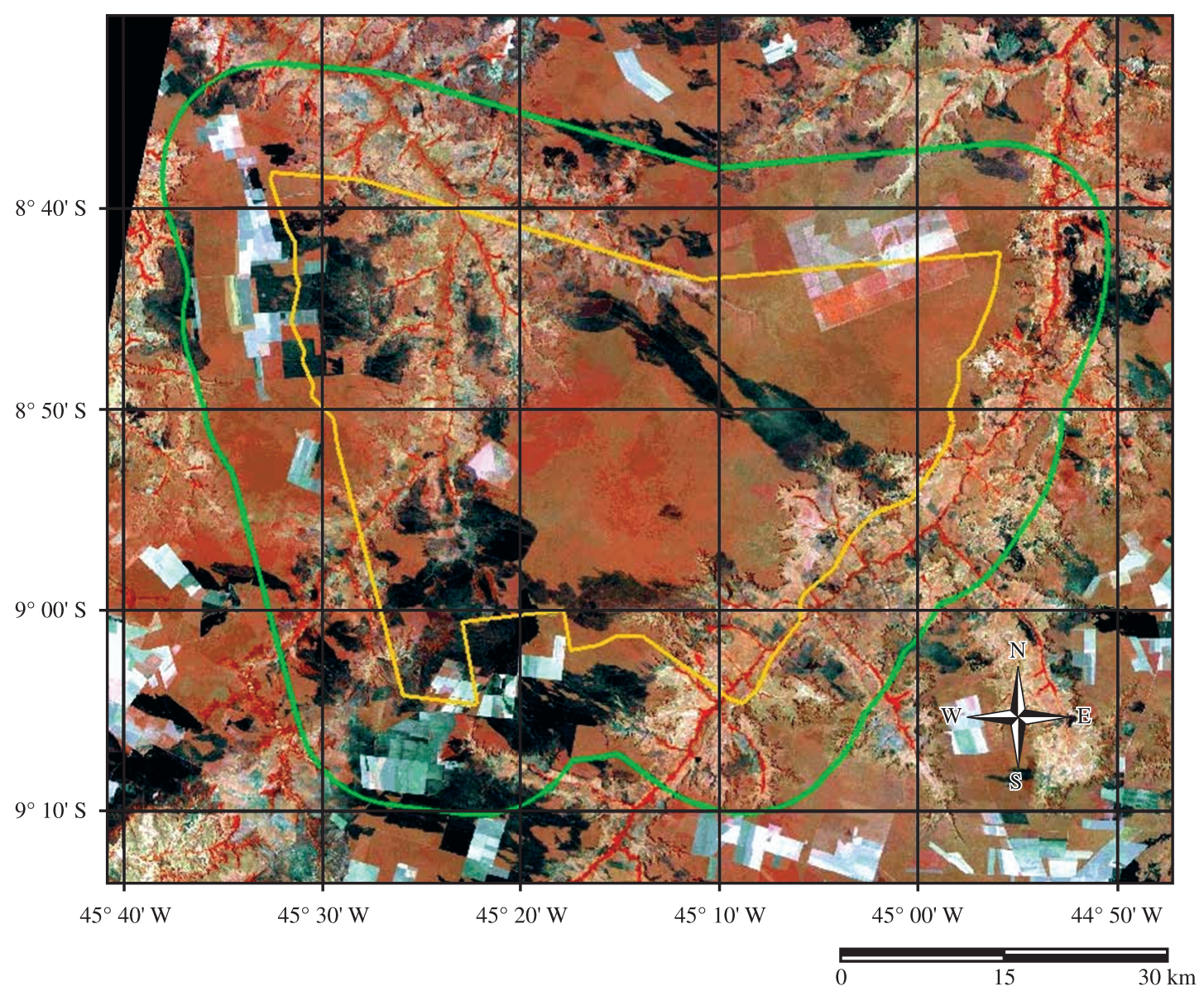

Figure 2. TM/Landsat-5 image from 24/09/2007, path/row 220/66, in false-colour composite (band 3 in blue, 4 in red and 5 in green). The limit of the Uruçuí-Una Ecological Station, Piauí, Brazil, is in yellow and of its buffer zone is in green.

Table 3. Colours of objects on true and false colour composites of the orbital images.

\begin{tabular}{lccccc}
\hline & Class & & \multicolumn{2}{c}{ Colour } & \multirow{2}{*}{ Texture } \\
\hline Primary & Secundary & & True composite & False composite & \\
\cline { 4 - 5 } Deforestation & Bare soil & & White-magenta & White-cyan & Smooth \\
& Green agriculture/pasture & & Green & Red & Smooth \\
& Dry straw & & Brown & Brown & Variable \\
& Regrowth & Green & Red & Rough \\
\hline Burning & Charcoal + ash & Black-magenta & Black-cyan & Smooth \\
& Soil without charcoal/ash & Magenta & Cyan & Rough \\
& Regrowth & Intense-green & Intense-red & Smooth \\
\hline Native vegetation & Grass & Light-green & Light-red & Rough \\
& Gallery forest & Intense-green & Intense-red & Smooth \\
\hline
\end{tabular}

fire to the vegetation at the end of the dry season to clear areas for new agriculture and pastures, thus using the new vegetation that sprouts after the fire to feed cattle. This practice constitutes the greatest cause of burn-offs in the Cerrado (Coutinho, 1990). In the UUES and its buffer zone the burning scars were larger at the end of the dry season compared to the mid-season periods in all years analysed (Table 4 and see Figure $3 b$ ).
França et al. (2007) studied the fire in Emas National Park, southwest Goiás, and observed that the dry phytomass increased along the time after the removal of cattle and abolition of anthropogenic burnings inside this conservation area. Every three years its amount was critical enough to extensively spread through the native vegetation the fire originated in plantations and pastures outside the Park. Although burning scars were detected in all periods analysed, 


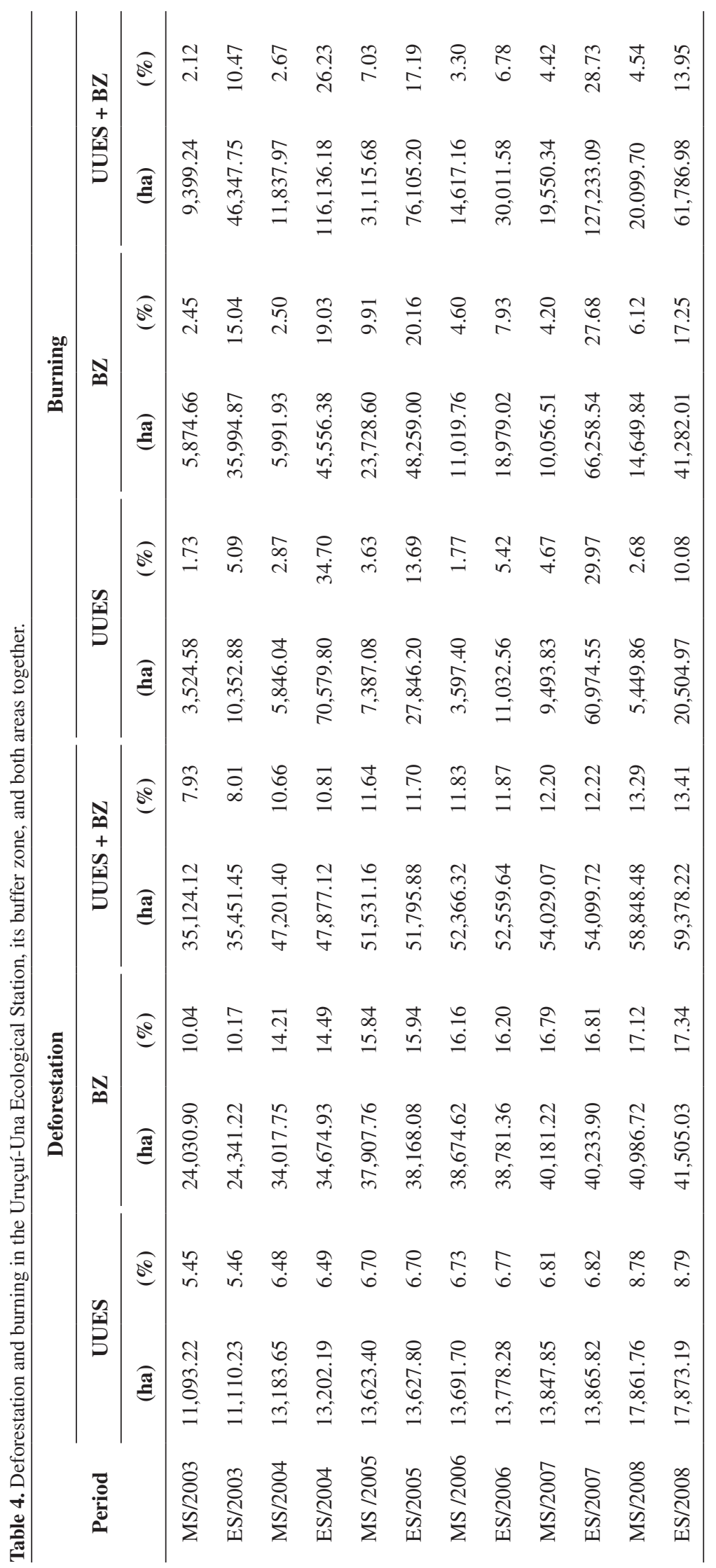



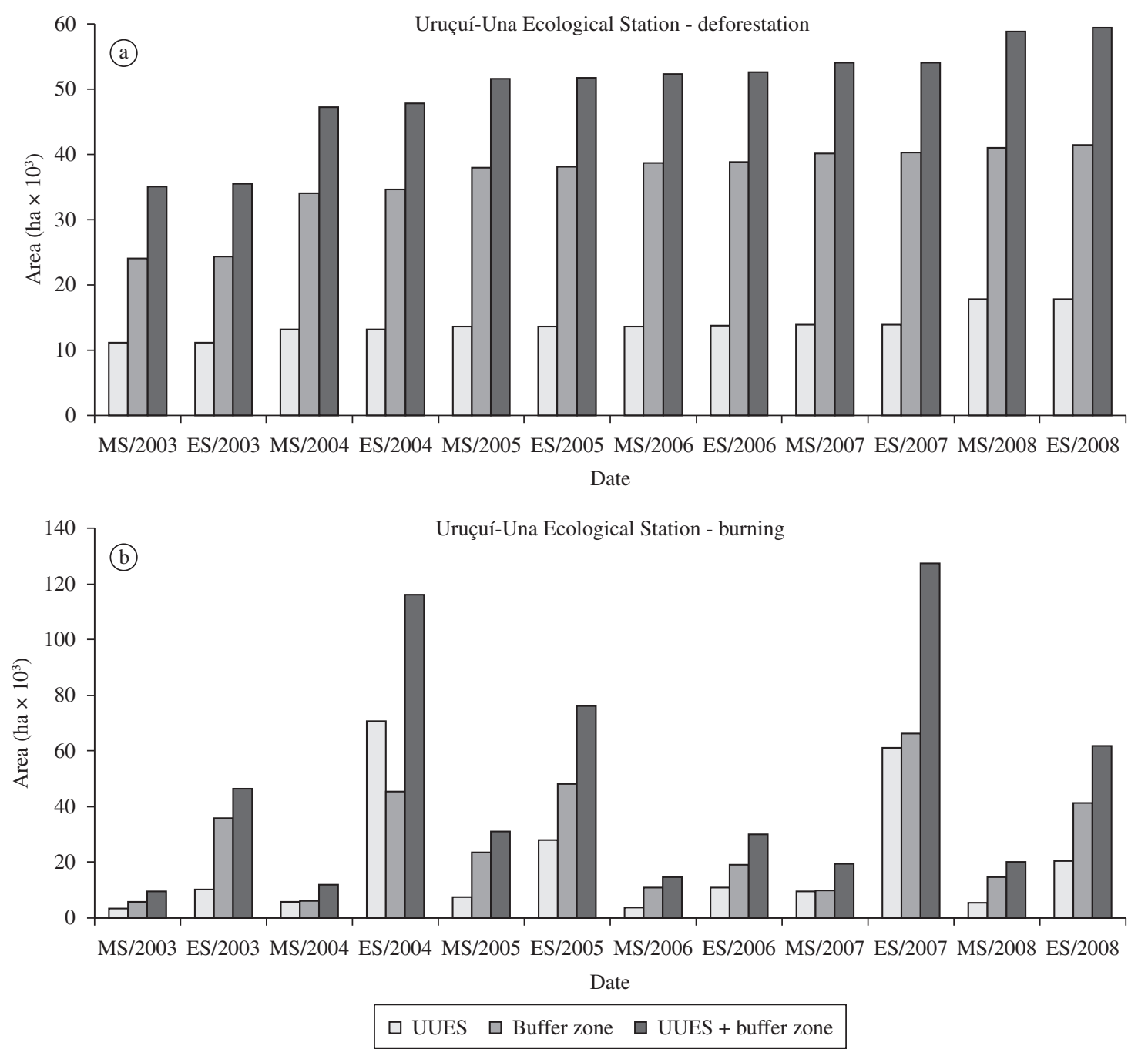

Figure 3. a) Deforestation; and b) burning in the Uruçuí-Una Ecological Station, Piauí, Brazil, its buffer zone and both areas together, for the middle and the end of dry season.

they were considerably larger in the UUES in 2004 and 2007 , indicating an interval of three years between big fire events. Since the same is not true considering the buffer zone alone, it's possible to presume that every three years, similarly to Emas National Park, large areas in the UUES region are affected by the increase of dry biomass and fire originated in plantations and pastures as well (Table 4 and see Figure 3b).

\section{Discussion}

The UUES region is among the most preserved portions of Cerrado, though from 2002 to 2008 it had been one of the most deforested (MMA, 2009a). We detected an annual deforestation rate of $1.46 \%$ in the buffer zone which is higher than the one of the entire Cerrado biome that was $1.04 \%$ (MMA, 2009a). The rate in the UUES was $0.67 \%$ / year, suggesting relative protection.
The Cerrado Biome had an annual deforestation rate of 21,300 $\mathrm{km}^{2} /$ year from 2002 to 2008 (MMA, 2009a), which is more than Amazonian deforestation for the same period, $18,487 \mathrm{~km}^{2} /$ year, and approximately double the amount from 2007 to 2008 which was $12,911 \mathrm{~km}^{2} /$ year (INPE, 2009). Furthermore, at least $48 \%$ of the Cerrado has been deforested (MMA, 2009a) while the Amazon has had a loss of $20 \%$ (Sawer, 2009). Controversially the Cerrado is far behind in terms of conservation, since $7.4 \%$ of its domain is in Conservation Units compared with $24.3 \%$ of the Amazon and the minimum of $10 \%$ recommended by the International Union for the Conservation of Nature (IUCN) (MMA, 2009b).

There exist no official programmes or politics to control the deforestation in the Cerrado or even a systematic monitoring as there is in the Amazon. At least implicitly, current policies seem to admit the sacrifice of the Cerrado, 
despite it being a global hotspot (Myers et al., 2000), as if it was an alternative to save the Amazon (Sawer, 2009).

Sawer (2009) estimates that the emissions of carbon in the Amazon has decreased to $112 \mathrm{TgC} /$ year as a consequence of the reduction of deforestation to about $12,000 \mathrm{~km}^{2} /$ year. In the Cerrado the emissions resulting from the deforestation of about 22,000 km²/year would be $100 \mathrm{TgC} /$ year, about $10 \%$ less than in the Amazon. However, according to Sawer (2009), we should note that these data only consider carbon in the aerial phytomass. While in the Amazon about $21 \%$ of the total phytomass is underground, in the Cerrado this proportion is a lot larger because of the deep roots, approximately $70 \%$.

While the carbon uptake, mainly carbon dioxide, in the Amazon resulting from the regeneration of the forest would be $35 \mathrm{TgC} /$ year, in the Cerrado it would be $200 \mathrm{TgC} /$ year (Sawer, 2009). However, frequent burnings in the Cerrado limit the spontaneous uptake of carbon dioxide that would occur if the arborous species could reach adulthood instead of dying prematurely by fire (Sawer, 2009). These fires were observed in the UUES region in all periods analysed as a consequence of anthropogenic burnings for the management and implementation of agriculture and pasture areas.

In Brazil little has been done in Conservation Units besides basic administration, like controlling the entrance of visitors and maintenance of infrastructure: bridges, roads, etc (França et al., 2007). The UUES doesn't even have a management plan and has only one employee (IBAMA, 2004), which results in the establishment of harmful practices to its ecosystems. In a visit to the UUES to study vertebrates, Zaher (2001) noted that the model adopted by the population that lives in the Station is negative, with the deforestation of riparian forests, burnings and hunting, which diminishes the richness and abundance of species in that region. This scenario together with the results obtained in this study reaffirms the urgent need: for a stronger enforcement in order to stop the anthropisation in the UUES; the creation of a management plan and the admission of new employees since there has been only one until 2009.

The Cerrado is one of the largest biomes in Brazil and its size and biodiversity justify its importance. However, anthropogenic interferences risk its integrity, as can be noticed in the results of this research. It is expected that studies like the one presented here will offer grounds for the proper management of conservation areas in this biome and for the implementation of new ones.

Acknowledgements - To Instituto Nacional de Pesquisas Espaciais (INPE), Conselho Nacional de Desenvolvimento Científico e Tecnológico (CNPq) and Bacabal Transportes.

\section{References}

Aguiar, LMS., Machado, RB., Marinho-Filho, J., 2004. A Diversidade Biológica do Cerrado. In AGUIAR, LMS. and CAMARGO, AJA. (Eds.). Cerrado: Ecologia e Caracterização. Brasília: Embrapa Informação Tecnológica, p. 17-40.
BRASIL, 1990. Resolução CONAMA No O13/1990. Dispõe Sobre a Área Circundante, Num Raio de 10 (Dez) Quilômetros, Das Unidades De Conservação. Available from: <http://www. mma.gov.br/port/conama/legiabre.cfm?codlegi $=110>$. Access in: 19 Oct. 2009

-, 1981. Decreto No 86.061/1981. Cria Estações Ecológicas, e dá Outras Providências. Available from: <http://www.ibama. gov.br/siucweb/mostradoclegal.php?seq_uc=34\&seq_tp_ documento $=3 \&$ seq_finaliddoc $=7>$. Access in: 19 Oct. 2009.

Coutinho, LM., 1990. Fire in the Ecology of the Brazilian Cerrado. In GOLDAMMER, JG. (Ed.). Fire in the Tropical Biota: Ecosystem Processes and Global Challenges. Berlim: Springer-Verlag, p. 82-103.

França, H. and Setzer, A., 2001. AVHRR Analysis of a Savanna Site Through a Fire Season in Brazil. International Journal of Remote Sensing, vol. 22, no. 13, p. 2449-2461.

França, H., Ramos Neto, MB. and Setzer, A., 2007. O Fogo no Parque Nacional das Emas. Brasília: MMA, 140 p. Available from: <http://www.mma.gov.br/estruturas/chm/_arquivos/livro\%20 parque\%20nacional\%20emas.pdf $>$. Access in: 19 Oct. 2009.

Instituto Brasileiro de Geografia e Estatística - IBGE, 2004. Mapa de Vegetação do Brasil. Rio de Janeiro: IBGE. Available from: <ftp://geoftp.ibge.gov.br/mapas/tematicos/mapas_murais/ vegetacao.pdf $>$. Access in: 19 Oct. 2009

Instituto Brasileiro do Meio Ambiente e dos Recursos Naturais Renováveis - IBAMA, 2004. Unidades De Conservação. Available From: <http://www.ibama.gov.br/siucweb/listauccategoria. php?abrev=esec $>$. Access in: 19 Oct. 2009.

Instituto Nacional de Pesquisas Espaciais - INPE, 2009. Available from: <http://www.obt.inpe.br/prodes/prodes_1988_2008.htm>. Access in: 19 Oct. 2009.

Instituto Nacional de Pesquisas Espaciais - INPE, 2008a. SPRING. Available from: <http://www.dpi.inpe.br/spring >. Access in: 19 Oct. 2009.

-, 2008b. Catálogo de Imagens. Available from: <http://www. dgi.inpe.br/cdsr>. Access in: 19 Oct. 2009.

Machado, RB., Ramos Neto, MB., Pereira, PGP., Caldas, EF., Gonçalves, DA., Santos, NS., Tabor, K. and Steininger, M., 2004. Estimativas de Perda da Área do Cerrado Brasileiro. Brasília: Conservação Internacional do Brasil, 23 p. Relatório Técnico. Available from: <http://www.conservation.org.br/arquivos/ relatdesmatamcerrado.pdf>. Access in: 19 Oct. 2009.

Mantovani, JE. and Pereira, A., 1998. Estimativa da Integridade da Cobertura Vegetal de Cerrado Através de Dados TM/Landsat. In Anais IX Simpósio Brasileiro de Sensoriamento Remoto, 11-18 setembro, 1998. São José dos Campos: INPE, p. 1455-146. Available from: <http://marte.dpi.inpe.br/col/sid.inpe.br/deise/1999/02.11.10.57/ doc/2_168p.pdf>. Access in: 19 Oct. 2009.

Ministério do Meio Ambiente - MMA, 2009a. Monitoramento do Bioma Cerrado - 2002 a 2008. Available from: <http://www. mma.gov.br/estruturas/sbf_chm_rbbio/_arquivos/relatorio_cerrado_ site_72_1.pdf>. Access in: 19 Oct. 2009.

-, 2009b. Plano de Ação Para Prevenção e Controle do Desmatamento e das Queimadas no Cerrado - PPCERRADO. Available from: $<$ http://www.mma.gov.br/estruturas/182/_arquivos/ppcerrado_ consultapublica_182.pdf>. Access in: 19 Oct. 2009. 
SAWER, D., 2009. Fluxos de Carbono na Amazônia e no Cerrado: um Olhar Socioecossistêmico. Sociedade e Estado, vol. 24, no. 1 , p. 149-171.

MYERS, N.; MITTERMEIER, R.A.; MITTERMEIER, C.G.; FONSECA, G.A.B.; KENT, J. 2000. Biodiversity hotspots for conservation priorities. Nature, vol. 403, p. 853-858.

PEREIRA JR, A.C. 1992. Monitoramento de queimadas na região dos Cerrados utilizando dados AVHRR/NOAA corrigidos por dados TM/LANDSAT. São José dos Campos: INPE. 220 p. INPE-5490-TDI/507.
SMITH, J., WINOGRAD, M., GALLOPIN, G. and PACHITO, D., 1998. Dynamics of the Agricultural Frontier in the Amazon and Savannas of Brazil: Analyzing the Impact of Policy and Technology. Environmental Modeling and Assessment, vol. 3, no. 1-2, p. 31-46.

University of Maryland, 2009. Global Land Cover Facility: Earth Science Data Interface. Available from: <http://glcfapp.umiacs. umd.edu:8080/esdi/index.jsp>. Access in: 19 Oct. 2009.

ZAHER, HED., 2001. Projeto Diversidade de Vertebrados Terrestres da Estação Ecológica de Uruçuí-Una, Piauí (PI): Subsídios para o Plano de Manejo. Curitiba: Fundação O Boticário, 110 p. 